\title{
Alginate Matrices for Protein Delivery - a Short Review
}

\author{
E. WAWRZYŃSKA ${ }^{1}$, D. KUBIES ${ }^{1}$ \\ ${ }^{1}$ Institute of Macromolecular Chemistry of the Czech Academy of Sciences, Prague, Czech \\ Republic
}

Received May 25, 2018

Accepted June 28, 2018

\section{Summary}

Growth factors are powerful molecules that regulate cellular growth, proliferation, healing, and cellular differentiation. A delivery matrix that incorporates growth factors with high loading efficiencies, controls their release, and maintains bioactivity would be a powerful tool for regenerative medicine. Alginate has several unique properties that make it an excellent platform for the delivery of proteins. Mild gelling conditions can minimize the risk of protein denaturation; moreover, alginate can serve as protection from degradation until protein release. Various modifications have been proposed to tune alginate binding and release proteins, simultaneously adjusting alginate degradability, mechanical stiffness, swelling, gelation properties and cell affinity. The primary objective of this article is to review the literature related to recent advances in the application of alginate matrices in protein delivery in regenerative medicine. A special emphasis is put on the relevance of delivery of growth factors and chemokine.

\section{Key words}

Alginate $\bullet$ Biomaterials $\bullet$ Protein release $\bullet$ Growth factor release

\section{Corresponding author}

E. Wawrzyńska, Institute of Macromolecular Chemistry of the Czech Academy of Sciences, Heyrovského nám. 2, 16206 Prague 6, Czech Republic. E-mail: wawrzynska@imc.cas.cz

\section{Introduction}

Alginate is an anionic and hydrophilic polysaccharide derived from the cell walls of brown seaweed and several bacteria strains. This linear copolymer consists of homopolymeric blocks of 1,4-linked $\beta$-D-mannuronate (M) and $\alpha$-L-guluronate $(\mathrm{G})$ residues. Blocks can be composed of consecutive $\mathrm{G}$ residues (G-blocks), consecutive $\mathrm{M}$ residues (M-blocks), and alternating $\mathrm{M}$ and $\mathrm{G}$ residues (MG-blocks) (Fig. 1). Depending on the source of alginate, the composition (i.e. $\mathrm{M} / \mathrm{G}$ ratio) and sequence of blocks may differ (Szekalska et al. 2016, Lee et al. 2012). Alginic acid is insoluble in water; however, alginate monovalent salts and alginate esters are water-soluble and form stable viscous solutions (Venkatesan et al. 2015).

Alginates exhibit various advantageous properties desirable in biomedical applications. They are considered to be biocompatible, non-toxic and non-immunogenic. Moreover, alginates can be gelled with multivalent cations under gentle conditions, which offer a welcome opportunity for entrapment of sensitive materials such as proteins, cells or DNA. Alginates or their gels can also be chemically and physically modified to alter their properties, functions and applications (Pawar et al. 2012). In addition, alginates can be easily processed into various three-dimensional scaffold materials such as hydrogels, microspheres, microcapsules, sponges, foams and fibers (Venkatesan et al. 2015, Jerome et al. 2016, Sun et al. 2013, Ahmed et al. 2015). Due to the abovementioned properties and potential applications, alginates have drawn enormous attention from researchers in the field of regenerative medicine. They have been broadly investigated as scaffolds for tissue engineering, including wound healing, bone regeneration and cartilage repair (Sun et al. 2013, August et al. 2006, Kuo and Ma 2001, Venkatesan et al. 2015, Koehler et al.2018, Lee et al. 2012). They are intended to mimic the cell and organ-interactive functions of the extracellular 
matrix, as well as to create chemically beneficial environments by presenting ligands that specifically bind to cell receptors. During the past two decades, alginate matrices have been also extensively investigated as carriers for delivery of biomolecules such as growth factors, which can further promote and regulate new tissue development (August et al. 2006). The primary objective of this article is to review the literature concerning recent advances in the application of alginate matrices in protein delivery in biomedical applications with a special emphasis put on the relevance of growth factors and chemokine delivery. A summary of recently published articles is presented in Table 1. Earlier studies were covered in the work of Gombotz and Wee (1998).

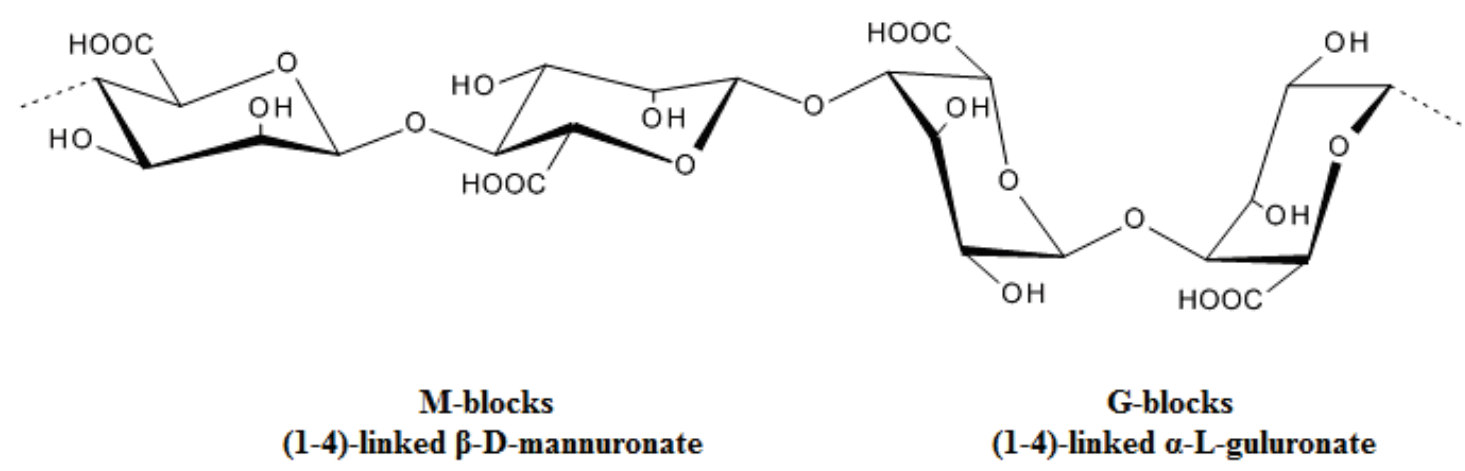

Fig. 1. The chemical structure of alginate.

Table 1. List of growth factors and other proteins encapsulated in alginate matrices studied in tissue engineering research. Recent studies.

\begin{tabular}{|c|c|c|c|}
\hline Protein(s) & References & $\begin{array}{l}\text { Preparation technique/ } \\
\text { modifications/form }\end{array}$ & $\begin{array}{l}\text { Releasing time/medium/ } \\
\text { method of quantification }\end{array}$ \\
\hline \multirow{7}{*}{$\begin{array}{l}\text { Vascular endothelial growth } \\
\text { factor (VEGF) }\end{array}$} & Lee et al. 2003 & $\begin{array}{l}\text { Needle extrusion/external } \\
\text { gelation, microbeads }\end{array}$ & DMEM, 12 days, gamma counter \\
\hline & Gu et al. 2004 & $\begin{array}{l}\text { Needle extrusion/external } \\
\text { gelation, microbeads }\end{array}$ & $\begin{array}{c}\text { PBS and fetal calf serum, from } 2 \\
\text { up to } 19 \text { days, ELISA }\end{array}$ \\
\hline & $\begin{array}{l}\text { Silva and Mooney } \\
2007\end{array}$ & $\begin{array}{l}\text { Combination of two molecular } \\
\text { weights of alginates (irradiated } \\
\text { and not), oxidation, casting } \\
\text { between glass plates }\end{array}$ & PBS, 32 days, gamma counter \\
\hline & Freeman et al. 2008 & $\begin{array}{l}\text { Study of protein interactions with } \\
\text { alginate sulfate (SPR analysis) }\end{array}$ & \\
\hline & $\begin{array}{l}\text { Freeman and Cohen } \\
\qquad 2009\end{array}$ & $\begin{array}{l}\text { Alginate-sulfate/alginate freeze- } \\
\text { dried microporous scaffolds, post } \\
\text { loading of growth factor }\end{array}$ & DMEM, 8 days, ELISA \\
\hline & $\begin{array}{l}\text { Jay and Saltzman } \\
\qquad 2009\end{array}$ & $\begin{array}{l}\text { Emulsification technique, } \\
\text { microparticles }\end{array}$ & $20 \%$ FBS-M199, 10 days, ELISA \\
\hline & $\begin{array}{l}\text { Silva and Mooney } \\
\qquad 2010\end{array}$ & $\begin{array}{l}\text { Combination of two molecular } \\
\text { weights of alginates (irradiated } \\
\text { and not), oxidation, injectable } \\
\text { hydrogel }\end{array}$ & PBS, 30 days, gamma counter \\
\hline
\end{tabular}




\begin{tabular}{|c|c|c|c|}
\hline $\operatorname{Protein}(s)$ & References & $\begin{array}{l}\text { Preparation technique/ } \\
\text { modifications/form }\end{array}$ & $\begin{array}{l}\text { Releasing time/medium/ } \\
\text { method of quantification }\end{array}$ \\
\hline \multirow{3}{*}{$\begin{array}{l}\text { Basic fibroblast growth factor } \\
\text { (bFGF) }\end{array}$} & Edelman et al. 1991 & $\begin{array}{l}\text { Heparin-Sepharose beads } \\
\text { encapsulated in alginate } \\
\text { microcapsules, needle } \\
\text { extrusion/external gelation, } \\
\text { post-loading of GF }\end{array}$ & $\begin{array}{l}\text { PBS with } 1 \% \text { gelatin, } 16 \text { days, } \\
\text { gamma counter }\end{array}$ \\
\hline & Lee et al. 2003 & $\begin{array}{l}\text { Needle extrusion/external } \\
\text { gelation, microbeads }\end{array}$ & DMEM, 12 days, gamma counter \\
\hline & Freeman et al. 2008 & $\begin{array}{l}\text { Alginate-sulfate/alginate } \\
\text { microspheres, needle } \\
\text { extrusion/external gelation }\end{array}$ & DMEM, 5 days, ELISA \\
\hline \multirow{2}{*}{$\begin{array}{l}\text { Fibroblast growth factor } 1 \\
(F G F-1)\end{array}$} & Moya et al. 2009 & $\begin{array}{l}\text { Needle extrusion/external } \\
\text { gelation, microbeads }\end{array}$ & $\begin{array}{c}0.9 \% \mathrm{NaCl} \text { and } 0.25 \% \mathrm{w} / \mathrm{v} \\
\mathrm{CaCl}_{2}, 21 \text { days, gamma counter }\end{array}$ \\
\hline & Khanna et al. 2010 & $\begin{array}{l}\text { Needle extrusion/external } \\
\text { gelation, microbeads }\end{array}$ & $\begin{array}{c}9 \% \mathrm{NaCl} \text { supplemented with } \\
2 \mathrm{mmol} / \mathrm{l} \text { of } \mathrm{CaCl}_{2}, 30 \text { days, } \\
\text { gamma counter }\end{array}$ \\
\hline
\end{tabular}

\begin{tabular}{|c|c|c|c|}
\hline & Freeman et al. 2008 & $\begin{array}{l}\text { Study of protein interactions with } \\
\text { alginate sulfate (SPR analysis) }\end{array}$ & \\
\hline $\begin{array}{l}\text { Platelet-derived growth } \\
\text { factor- } B B(P D G F-B B)\end{array}$ & $\begin{array}{l}\text { Freeman and Cohen } \\
\qquad 2009\end{array}$ & $\begin{array}{l}\text { Alginate-sulfate freeze-dried } \\
\text { microporous scaffolds, post } \\
\text { loading of GF }\end{array}$ & DMEM, 8 days, ELISA \\
\hline \multirow{2}{*}{$\begin{array}{l}\text { Transforming growth factor } \\
\text { (TGF- } \beta 1)\end{array}$} & Mumper et al. 1993 & $\begin{array}{l}\text { Needle extrusion/external } \\
\text { gelation, microbeads }\end{array}$ & $\begin{array}{l}\text { PBS, PBS with } 1 \% \mathrm{BSA} /, 0.1 \mathrm{~N} \\
\mathrm{HCl} \text {, up to } 28 \mathrm{~h}, \\
\text { ELISA and gamma counter }\end{array}$ \\
\hline & $\begin{array}{l}\text { Freeman and Cohen } \\
\qquad 2009\end{array}$ & $\begin{array}{l}\text { Alginate-sulfate freeze-dried } \\
\text { microporous scaffolds, post } \\
\text { loading of GF }\end{array}$ & DMEM, 8 days, ELISA \\
\hline $\begin{array}{l}\text { Recombinant glutathione-s- } \\
\text { transferase (GST), Green } \\
\text { fluorescent protein (GFP) }\end{array}$ & Momoh et al. 2015 & $\begin{array}{c}\text { Alginate with and without } \\
\text { plasticizer (GLY), mixing, films }\end{array}$ & $\begin{array}{c}\text { Simulated wound fluid containing } \\
0.02 \mathrm{M} \mathrm{CaCl}_{2}, 0.4 \mathrm{M} \mathrm{NaCl}, \\
0.08 \mathrm{M} \text { Tris-buffer and } 2 \%(\mathrm{w} / \mathrm{v}) \\
\text { BSA, Multi scan EX Micro-plate } \\
\text { photometer, Western blotting }\end{array}$ \\
\hline \multirow[b]{2}{*}{$\begin{array}{l}\text { Hepatocyte growth factor } \\
(H G F)\end{array}$} & Freeman et al. 2008 & $\begin{array}{l}\text { Study of protein interactions with } \\
\text { alginate sulfate (SPR analysis) }\end{array}$ & \\
\hline & Ruvinov et al. 2010 & $\begin{array}{c}\text { Alginate-sulfate, needle } \\
\text { extrusion/external gelation, } \\
\text { microbeads }\end{array}$ & $\begin{array}{l}\text { Medium M-199, } 7 \text { days, ELISA, } \\
\text { Western blotting }\end{array}$ \\
\hline $\begin{array}{l}\text { Endothelial cell growth } \\
\text { supplement (ECGS) }\end{array}$ & $\begin{array}{l}\text { Tilakaratne et al. } \\
\qquad 2006\end{array}$ & Hydrogel, external gelation & $\begin{array}{l}\text { PBS, } 142 \text { h, Coomassie Plus } \\
\text { Protein Micro Assay }\end{array}$ \\
\hline
\end{tabular}




\begin{tabular}{|c|c|c|c|}
\hline $\operatorname{Protein}(s)$ & References & $\begin{array}{l}\text { Preparation technique/ } \\
\text { modifications/form }\end{array}$ & $\begin{array}{l}\text { Releasing time/medium/ } \\
\text { method of quantification }\end{array}$ \\
\hline $\begin{array}{l}\text { Epidermal growth factor } \\
(\text { EGF), Insulin growth factor, } \\
\text { FLT, Stem cell factor, } \\
\text { Oncostatin, Thromboprotein, } \\
\text { Interleukin } 6\end{array}$ & Freeman et al. 2008 & $\begin{array}{l}\text { Study of protein interactions with } \\
\text { alginate sulfate (SPR analysis) }\end{array}$ & \\
\hline \multirow{6}{*}{$\begin{array}{l}\text { Stromal cell-derived factor } 1 \\
(C X C L 12)\end{array}$} & Freeman et al. 2008 & $\begin{array}{l}\text { Study of protein interactions with } \\
\text { alginate sulfate (SPR analysis) }\end{array}$ & \\
\hline & Rabbany 2010 & $\begin{array}{l}\text { Ionotropic gelation method, } \\
\text { freeze-dried hydrogels cross- } \\
\text { linked with ethylenediamine, } \\
\text { post-loading of chemokine }\end{array}$ & $\begin{array}{l}\text { PBS containing } 0.1 \mathrm{mg} / \mathrm{ml} \mathrm{BSA} \text {, } \\
150 \mathrm{~h} \text { in vitro, quantifying } \\
\text { radioactivity, } 14 \text { days in vivo }\end{array}$ \\
\hline & Wang and Irvine 2011 & $\begin{array}{l}\text { Emulsification technique, } \\
\text { microparticles, post-loading of } \\
\text { chemokine }\end{array}$ & $\begin{array}{l}\text { Phenol red-free RPMI medium } \\
\text { containing } 10 \% \text { fetal calf serum, } \\
\text { up to } 24 \mathrm{~h} \text {, ELISA }\end{array}$ \\
\hline & Henderson 2011 & $\begin{array}{l}\text { Ionotropic gelation, freeze-dried } \\
\text { hydrogels cross-linked with ED, } \\
\text { post-loading of the chemokine }\end{array}$ & No release studies \\
\hline & $\begin{array}{l}\text { Duncanson and } \\
\text { Sambanis } 2013\end{array}$ & $\begin{array}{l}\text { Microcapsules prepared by } \\
\text { electrostatic droplet generator }\end{array}$ & DMEM, 21 days, ELISA \\
\hline & Chen et al. 2015 & $\begin{array}{l}\text { Microbeads with encapsulated } \\
\text { murine or porcine islets }\end{array}$ & $\begin{array}{c}\text { DMEM with } 0.5 \% \text { BSA, } 25 \text { days, } \\
\text { ELISA }\end{array}$ \\
\hline $\begin{array}{l}\text { Interferon gamma-induced } \\
\text { protein } 10 \text { (CXCL10), CCL19 } \\
\text { (Macrophage inflammatory } \\
\text { protein-3 beta), CCL21 (C-C } \\
\text { motif chemokine ligand } 21 \text { ) }\end{array}$ & Wang and Irvine 2011 & $\begin{array}{l}\text { Emulsification technique, } \\
\text { microparticles, } \\
\text { post-loading of chemokine }\end{array}$ & $\begin{array}{l}\text { Phenol red-free RPMI medium } \\
\text { containing } 10 \% \text { fetal calf serum, } \\
\text { up to } 24 \mathrm{~h} \text {, ELISA }\end{array}$ \\
\hline
\end{tabular}

\begin{tabular}{|c|c|c|c|}
\hline \multirow{5}{*}{$\begin{array}{l}\text { Recombinant human bone } \\
\text { morphogenetic protein- } 2 \\
(r h B M P-2)\end{array}$} & Jeon et al. 2011 & $\begin{array}{l}\text { Irradiated alginate, } \\
\text { photocrosslinked heparin-alginate } \\
\text { hydrogels modified with RGD } \\
\text { sequences, }\end{array}$ & PBS, 21 days, ELISA \\
\hline & Kolambkar et al. 2011 & $\begin{array}{l}\text { Irradiated RGD-modified alginate } \\
\text { hydrogels casted into molds }\end{array}$ & PBS, 21 days, ELISA \\
\hline & Priddy et al. 2014 & $\begin{array}{c}\text { Irradiated-oxidized RGD } \\
\text { modified alginate hydrogels }\end{array}$ & PBS, 26 days, ELISA \\
\hline & Quinlan et al. 2015 & $\begin{array}{l}\text { Spray-dried microparticles } \\
\text { incorporated into collagen- } \\
\text { hydroxyapatite scaffold }\end{array}$ & PBS, 28 days, ELISA \\
\hline & $\begin{array}{l}\text { McDermott et al. } \\
2016\end{array}$ & $\begin{array}{c}\text { Irradiated and RGD } \\
\text { functionalized alginate, injectable } \\
\text { hydrogels incorporated into } \\
\text { polymer constructs }\end{array}$ & PBS, 21 days, ELISA \\
\hline
\end{tabular}




\begin{tabular}{|c|c|c|c|}
\hline Protein(s) & References & $\begin{array}{l}\text { Preparation technique/ } \\
\text { modifications/form }\end{array}$ & $\begin{array}{l}\text { Releasing time/medium/ } \\
\text { method of quantification }\end{array}$ \\
\hline $\begin{array}{l}\text { Bone forming peptide-1 } \\
\text { (BFP-1) }\end{array}$ & Luo et al. 2016 & Freeze-dried porous scaffolds & $\begin{array}{l}\text { PBS, } 21 \text { days, Fluorescence } \\
\text { Spectrophotometry }\end{array}$ \\
\hline \multirow{13}{*}{ Bovine serum albumin (BSA) } & Leonard et al. 2004 & Microparticles, external gelation & $\begin{array}{l}\text { Water, Tris-buffer, } 70 \mathrm{~h} \text {, } \\
\text { Fluorescence Spectrophotometry }\end{array}$ \\
\hline & Castro et al. 2005 & Beads, gelation & $\begin{array}{c}\text { PBS/citrate buffer, } 40 \text { min, } \\
\text { Coomassie Brilliant Blue dye } \\
\text { binding assay }\end{array}$ \\
\hline & Dai et al. 2005 & Microcapsules, external gelation & $\begin{array}{l}\text { HEPES buffer, } 30 \text { days, } \\
\text { UV spectrophotometry }\end{array}$ \\
\hline & Dai et al. 2006 & Microcapsules, external gelation & $\begin{array}{l}\text { HEPES buffer, } 30 \text { days, } \\
\text { UV spectrophotometry }\end{array}$ \\
\hline & $\begin{array}{l}\text { Wells and Sheardown } \\
2007\end{array}$ & $\begin{array}{l}\text { Needle extrusion/external } \\
\text { gelation, microbeads, post- } \\
\text { loading of protein }\end{array}$ & $\begin{array}{l}\text { PBS, TRIS buffered saline, } 0.15 \% \\
\mathrm{NaCl}, 200 \mathrm{~h} \text {, in some cases up to } \\
250 \text { days, Bradford assay }\end{array}$ \\
\hline & Sivadsa et al. 2008 & Spray-dried microparticles & $\begin{array}{c}\text { PBS, } 3 \text { h, UV spectrophotometry of } \\
\text { BSA-FITC }\end{array}$ \\
\hline & Stoppel et al. 2011 & $\begin{array}{l}\text { Internal gelation, hydrogels, } \\
\text { post loading of protein }\end{array}$ & Water, 2 h, BCA Protein Assay \\
\hline & Mobus et al. 2012 & Spray-dried microparticles & $\begin{array}{l}\text { Water, PBS, modified simulated } \\
\text { lung fluid, } 48 \mathrm{~h} \text { Coomassie assay }\end{array}$ \\
\hline & Liu et al. 2013 & $\begin{array}{l}\text { Internal gelation combined with } \\
\text { microfluidic emulsification, } \\
\text { microcapsules }\end{array}$ & No data \\
\hline & $\begin{array}{l}\text { Kaygusuz and Erim } \\
\qquad 2013\end{array}$ & Beads, gelation & $\begin{array}{c}\text { Simulated gastric fluid, simulated } \\
\text { intestinal fluid, } 8 \mathrm{~h} \text {, Bradford } \\
\text { protein assay }\end{array}$ \\
\hline & Hariyadi et al. 2014 & $\begin{array}{l}\text { BSA-loaded alginate gel } \\
\text { microspheres by aerosolisation }\end{array}$ & $\begin{array}{l}\text { PBS, simulated gastric fluid, } \\
\text { simulated intestinal fluid, } 24 \mathrm{~h} \text {, } \\
\text { BCA total protein assay }\end{array}$ \\
\hline & Eldin et al. 2015 & Microbeads, internal gelation & PBS, 5 h, UV spectroscopy \\
\hline & Bajpai et al. 2016 & $\begin{array}{c}\text { Hydrogel discs, Diffusion } \\
\text { Through Dialysis Tube (DTDT) } \\
\text { technique }\end{array}$ & PBS, 5 h, UV spectroscopy \\
\hline \multirow{2}{*}{ Lysozyme, Chymotrypsin } & $\begin{array}{l}\text { Wells and Sheardown } \\
2007\end{array}$ & $\begin{array}{l}\text { Needle extrusion/external } \\
\text { gelation, microbeads, post- } \\
\text { loading of protein }\end{array}$ & $\begin{array}{c}\text { PBS, TRIS buffered saline, } \\
0.15 \% \mathrm{NaCl}, 200 \mathrm{~h} \text {, Bradford } \\
\text { assay }\end{array}$ \\
\hline & $\begin{array}{c}\text { Rahmani and } \\
\text { Sheardown } 2018\end{array}$ & Hydrogels, external gelation & $\begin{array}{c}\text { Sodium acetate and sodium } \\
\text { phosphate buffer, } 3 \mathrm{~h} \text {, Bradford } \\
\text { assay }\end{array}$ \\
\hline
\end{tabular}




\begin{tabular}{lccc}
\hline Protein(s) & References & $\begin{array}{c}\text { Preparation technique/ } \\
\text { modifications/form }\end{array}$ & $\begin{array}{c}\text { Releasing time/medium/ } \\
\text { method of quantification }\end{array}$ \\
\hline Myoglobin, Cytochrome C & $\begin{array}{c}\text { Rahmani and } \\
\text { Sheardown } 2018\end{array}$ & Hydrogels, external gelation & $\begin{array}{c}\text { Sodium acetate buffer and sodium } \\
\text { phosphate buffer, up to } 3 \mathrm{~h}, \\
\text { Bradford assay }\end{array}$ \\
\hline $\begin{array}{l}\text { Kaposi fibroblast growth } \\
\text { factor At-MTS }\end{array}$ & Maurice et al. 2004 & $\begin{array}{c}\text { Needle extrusion/external } \\
\text { gelation, microbeads }\end{array}$ & $\begin{array}{c}\text { Tris buffer, } 2.5 \mathrm{~h} \text { mini-Bradford } \\
\text { method }\end{array}$ \\
\hline
\end{tabular}

\section{Model protein delivery}

BSA is commonly used as a model protein for encapsulation of lipophilic drugs, chemicals, and nutrients in studies dealing with preparation of alginatebased carriers mostly in the form of microparticles by different processing methods. As examples, we mention several representative approaches.

Alginate microparticles prepared by spraydrying processes have been studied for their application in nasal and pulmonary drug delivery. Sivadas et al. (2008) prepared inhalable alginate particles (of an average diameter $3.23 \pm 0.25 \mu \mathrm{m}$ ) with a high encapsulation efficiency of $97 \%$ with the preserved structure and thus bioactivity of BSA. The alginate particles released approximately $20 \%$ of the loaded BSA over $24 \mathrm{~h}$ and then a slow release occurred, reaching a cumulative release of only $35 \%$ after $180 \mathrm{~h}$. Möbus et al. (2012) prepared $\mathrm{Zn}^{2+}$-crosslinked alginate microparticles containing the model protein BSA via a simple one-step spray-drying process. The method led to particles with a diameter of $2-4 \mu \mathrm{m}$. The BSA release into the simulated lung fluid increased with an increasing content of protein in the alginate microparticles. For example, for microparticles with a $30 \%$ initiating loading, almost $100 \%$ of BSA was released within $24 \mathrm{~h}$ in comparison with $10 \%$ loading microparticles with a cumulative release of $55 \%$.

Alginate hydrogels have also been studied for oral delivery of proteins. Hariyadi et al. (2014) prepared alginate microspheres that were 25 to $65 \mu \mathrm{m}$ in size and with protein loading of $3.3 \%$. The BSA release from the hydrated microparticles reached less than $7 \%$ in the simulated gastric fluid over $2 \mathrm{~h}$, whereas $90 \%$ of the protein load was gradually released in the simulated intestinal fluid over $10 \mathrm{~h}$. The release from freeze-dried particles was significantly faster. Kaygusuz et al. (2013) prepared alginate particles containing montmorillonite (MMT) with a diameter of $2 \mathrm{~mm}$. Incorporation of MMT significantly enhanced the BSA loading to $78 \%$ in comparison to $40 \%$ evaluated for conventional alginate beads. The presence of MMT also decreased the release both in simulated gastric as well as intestinal fluid.

BSA and hemoglobin were used as model proteins to evaluate the protein release from microbeads (1 mm) prepared from alginate with covalently bound long alkyl chains (Leonard et al. 2004). Under predefined processing conditions, the modified alginate enabled a high protein encapsulation (90-100\%). The microbeads prepared from such amphiphilic alginate derivatives exhibited almost no release of both BSA and hemoglobin, e.g. biomolecules that do not interact ionically with the alginate matrix. The authors highlighted a strong contribution of hydrophobic interactions between the tested proteins and hydrophobic alkyl chains in alginate hydrogels for the protein retention. However, addition of the enzyme lipase initiated protein release via dissociation of the physical hydrophobic network of the alginate microspheres.

BSA was also used to study the efficiency of carrier-microencapsulated liposome systems based on encapsulation of BSA-containing multivesicular liposomes (MVLs) into alginate microbeads (Dai et al. 2006). The proposed carrier preparation led to high encapsulation efficiency of BSA/liposomes and only to minor changes in the chemistry of the drug. The effect of various processing parameters on particle size and encapsulation efficiency of MVLs was evaluated. In addition to other parameters, the authors found that crosslinking with $\mathrm{Ba}^{2+}$ ions led to circular particles with a uniform size and with the highest BSA entrapment rate (up to $95 \%$ ) in comparison with crosslinking with $\mathrm{Ca}^{2+}$ and $\mathrm{Al}^{3+}$ ions. In vitro BSA release into HEPES buffer exhibited sustained BSA release over 2 weeks.

The most common procedure of protein encapsulation in alginate matrix is an addition of protein to the alginate solution prior to crosslinking. However, the difference in protein concentration between the gel 
and the vast volume of the crosslinking solution might cause diffusion, resulting in significant protein loss during gelation. Therefore, a quick encapsulation method performed post-synthesis would be more effective, minimizing protein loss and increasing loading efficiency. Wells et al. proposed a new encapsulation technique for high isoelectric point proteins, i.e. lysozyme $(\mathrm{pI}=11.0)$ and chymotrypsin $(\mathrm{pI}=9.1)$ and for a model protein albumin $(\mathrm{pI}=4.7)$ into alginate microcapsules; here, the microcapsules were incubated with a protein-containing $\mathrm{NaCl}$ solution and subsequently re-crosslinked with $\mathrm{CaCl}_{2}$ (Wells and Sheardown 2007). The proposed method allowed for the incorporation of significantly higher amounts of isopositive proteins chymotrypsin and lysozyme that otherwise crosslinked alginate. Further, more than twice as much lysozyme was incorporated into the spheres when loaded from the solution containing degradative $\mathrm{NaCl} \quad(0.15 \%)$ ( $8 \mu \mathrm{mol} /$ gram of alginate) contrary to a water solution alone $(3.4 \mu \mathrm{mol} / \mathrm{gram}$ of alginate). On the other hand, similar BSA loadings were observed regardless the loading method used. The protein release depended on the supernatant type. The high pI proteins chymotrypsin and lysozyme showed relatively constant delivery into $0.15 \% \mathrm{NaCl}$ over more than 3 months. Whereas when released in a TRIS buffered saline, both proteins showed a sustained release lasting over $150 \mathrm{~h}$. On the contrary, for the case of PBS, all three proteins were delivered in a burst release due to the high concentration of degradative phosphate ions within the medium. The group postulated that the sustained release of lysozyme and chymotrypsin indicates that electrostatic interactions of proteins with alginate play a dominant role in the release kinetics and affect diffusive properties of the protein in the alginate (a quick diffusion of negatively charged proteins and a slower diffusion of positively charged proteins). In vitro test demonstrated that the released lysozyme remained its active for at least 16 days.

\section{Angiogenic factors delivery}

Growth factors (GF) regulate a variety of cellular behaviors including growth, migration, differentiation, apoptosis, and cell survival. They act during development and play important roles in the maintenance of tissue homeostasis and wound healing processes. Secreted growth factors act on nearby cells through paracrine or contact juxtacrine signaling to mediate short-range cell-to-cell communications. Only when GF binds in a proper manner to a transmembrane enzyme-linked receptors in the membrane of the responding cell, the receptor will be activated and this process will promote a cascade of intracellular processes leading to changes in the behavior of the target cells through the direct regulation of transcription factors, or through the regulation of mRNA stability or protein translation (Lodish et al. 2000). Therefore regardless if GF is delivered in a soluble form via diffusion from the matrix or if it is bound to the substrate, the ligand site has to be available for their interaction with cell receptors.

Neovascularization and angiogenesis play an important role in wound healing as it involves the growth of new blood vessels to form granulation tissue. This dynamic process is highly regulated by signals from both serum and the surrounding extracellular matrix (ECM) environment. Vascular endothelial growth factor (VEGF), fibroblast growth factor (FGF), transforming growth factor beta (TGF), and platelet-derived growth factor-BB (PDGF-BB) are among the potent angiogenic growth factors in wound angiogenesis (Honnegowda et al. 2015, Bouis et al. 2006). Their loading into alginate hydrogels and subsequent protein release behavior can be controlled by regulating the conditions of microcapsule preparation.

A comprehensive study on VEGF encapsulation into alginate microbeads and VEGF release was performed by Gu et al. (2004). In this work, the influence of VEGF loading concentrations, alginate gelation parameters (alginate concentration, G-block content, types and concentrations of additives, as well as types and concentrations of cations in the gelling bath) and the releasing medium composition on VEGF loading and release was thoroughly examined. The authors reported that with increasing VEGF concentrations in the alginate mixtures $(0.2,2$ and $20 \mu \mathrm{g} / \mathrm{ml})$, the encapsulation yield decreased significantly $(92.7 \%, 69.4 \%$, and $48.3 \%$, respectively). After one day incubation in PBS or serumcontaining media, the alginate gel with a loading of $20 \mu \mathrm{g} / \mathrm{ml}$ showed the highest initial protein burst $(\sim 50 \%$ and $\sim 70 \%$, respectively) followed by a continuous release into PBS at a rate of $4.4 \%$ per day for 6 days. Other VEGF payloads showed a lower initial release $(\sim 10 \%$ for $0.2 \mu \mathrm{g} / \mathrm{ml}$ and $\sim 30-40 \%$ for $2 \mu \mathrm{g} / \mathrm{ml})$ followed by very low release levels. Neither VEGF encapsulation yield nor the release behavior was affected by the alginate concentration $(1.5 \%, 2 \%$, or $3 \%)$. Also no significant difference in VEGF retention was observed for alginates with high and low G-block content. In 
contrast, an increasing BSA loading concentration (added into the alginate matrix to mask electrostatic interactions) decreased the encapsulation yield.

Moreover, the concentration of $\mathrm{CaCl}_{2}$ in the releasing medium greatly affected the profile of VEGF release; the amount of the eluted protein increased with increasing concentrations of $\mathrm{Ca}^{2+}$ cations. Specifically, approximately $22.3 \%$ of VEGF was released into supernatant with $0.1 \mathrm{M} \mathrm{CaCl}_{2}$ within 19 days. In contrast, almost $100 \%$ of protein was released into the highest $\mathrm{CaCl}_{2}$ concentration investigated $(1 \mathrm{M})$. However, this system showed a very high initial burst where almost $85 \%$ of VEGF was delivered within the first $72 \mathrm{~h}$. The releasing medium with $0.5 \mathrm{M}$ concentration of $\mathrm{CaCl}_{2}$ led to a constant release rate of $6 \mathrm{ng} / \mathrm{ml} /$ day over 14 days. However, such high concentration of $\mathrm{CaCl}_{2}$ cannot be used therapeutically.

A low concentration of $\mathrm{Na}^{+}$or $\mathrm{Mg}^{2+}$ cations $(0.1 \mathrm{M})$ in gelling medium increased VEGF encapsulation yields $\left(\mathrm{Na}^{+} 97.9 \%, \mathrm{Mg}^{2+} 98.9 \%\right.$, control $92.7 \%)$. As the concentrations of cations increased to $0.5 \mathrm{M}$ or $1 \mathrm{M}$, the encapsulation yields were lower than the control. The authors attributed higher retention yields to an appropriate amount of the ions required to create a homogenous gel of smaller average pore size, which slowed the rate of the VEGF release. An addition of $\mathrm{NaCl}$ or $\mathrm{MgCl}_{2}$ over $0.5 \mathrm{M}$ into the releasing medium maintained the VEGF release in a similar manner to the $\mathrm{CaCl}_{2}$ containing supernatant; however, those alginate hydrogels disintegrated in those supernatants after one week.

Jay and colleagues investigated the VEGF release from alginate matrices gelled by various ionic crosslinkers (different salts and concentrations were studied) (Jay and Saltzman 2009). The mixing of alginate microparticles crosslinked by $\mathrm{Zn}^{2+}$ and $\mathrm{Ca}^{2+}$ allowed for a controlled and sustained VEGF release, the particles were non-cytotoxic, and the released VEGF retained its bioactivity. Lee et al. (2003) monitored the release of radiolabeled VEGF and bFGF from alginate beads into Dulbecco's Modified Eagle Medium (DMEM). The authors reported a sustained release profile of both growth factors with an almost zero-order release rate for the initial time periods and a small slowdown later in the experiment. Alginate hydrogels eluted approximately $55 \%$ of the loaded bFGF within 12 days and approximately $70 \%$ of VEGF within 10 days in DMEM.

The FGF-1 delivery from alginate microbeads in order to induce neovascularization in vivo was investigated by Moya et al. (2009). The release profile of radiolabeled FGF-1 revealed a high initial burst ( $\sim 90 \%)$ during the first 3 days, followed by a constant release of small amounts of FGF-1 over 3 weeks. The microbeads loaded with FGF-1 (total amount $150 \mathrm{ng}$ ) were implanted into a surgically created omental pouch in rats. Three weeks after implantation, the calculated vascular area for the FGF-1 loaded microbeads and for the bolus FGF-1/empty microbead control did not significantly differ, but both were higher than that observed for the empty microbead control. Six weeks after implantation, the vascular density evaluated for the FGF-1 loaded microbeads was significantly higher than the density observed for both control groups. Moreover, staining for smooth muscle actin revealed that $50 \%$ of the vessels had associated mural cells. A trend of increased mural cell staining at 6 weeks for the FGF-1 loaded alginate beads was reported as well.

Diffusion is a predominant mechanism of growth factor release from non-degradable alginate hydrogels; however, protein release can be additionally tuned by matrix degradation. This scenario can be achieved by control over molecular weight, e.g. by gamma-irradiation of a polymer or by use of a binary molecular weight formulation to allow the polymers to more readily dissociate from the alginate matrix. The matrix degradation can be also enhanced by partial oxidation of urinate residues in order to make polymer chains susceptible to hydrolysis. Silva's group investigated the influence of alginate oxidation on the release of ${ }^{125}$ I-labeled VEGF into PBS (Silva and Mooney 2007). The samples were prepared in the form of hydrogel blocks crosslinked with calcium slurry from mixtures of high $(250,000 \mathrm{Da})$ and low molecular weight $(50,000 \mathrm{Da})$ alginates subjected previously to oxidation with sodium periodate. The oxidized alginate matrix showed enhanced protein release into PBS especially at the beginning of the experiment. Approximately $60 \%$ of the loaded VEGF was released within the first 7 days, followed by a slower release leading to approximately $80 \%$ of overall released VEGF after 33 days. The nonoxidized alginate hydrogel delivered VEGF at a much slower rate, releasing only $\sim 40 \%$ of the entrapped VEGF after 30 days. The release profiles corresponded to degradation rates of the alginate matrices. The oxidized samples degraded more rapidly. After 6 days, approximately $45 \%$ and $20 \%$ of mass loss was detected for oxidized and non-oxidized alginate matrices, respectively. Within 40 days the oxidized hydrogels had 
almost completely degraded ( $\sim 80 \%$ mass loss), while the non-oxidized alginates showed a mass loss of approximately $35 \%$. Importantly, in vitro tests revealed that VEGF released from the alginate matrix during the first 4 days was bioactive and even more effective than VEGF added directly to the culture medium. Moreover, the VEGF-alginate system promoted a 2.5 greater number of endothelial cell sprouts in comparison to the VEGF control. The in vivo experiment showed that the VEGFalginate injectable system exhibited a controlled and localized delivery of growth factors in ischemic hindlimbs, releasing a higher level of VEGF in hypoxic regions than a bolus injection. The proposed injectable VEGF-alginate systems were further investigated in vivo elsewhere (Silva and Mooney 2010).

Most of the delivery systems are designed to deliver one growth factor in a single system; however, it has been shown that it is usually a certain combination of growth factors with different impacts on cell behavior which synergistically stimulate activity of cells in particular physiological in vivo processes (Wang et al. 2017). For example, in the first stage of angiogenesis, VEGF, FGF-2 and angiopoietin-2 stimulate disruption of preexisting blood vessels as well as migration and proliferation of endothelial cells into the place of the new formed immature vessels (Lee et al. 2011). Whereas in the second stage angiopoietin-1 and PDGF initiate pericyte recruitment into the place of vessel formation and thus promote stabilization of newly formed capillaries (Rouwkema et al. 2016). Therefore delivery of a cocktail of GFs to the place of implantation would be more effective in successful vascularization than delivery of individual growth factors.

Freeman and Cohen proposed a strategy for the sequential delivery of three angiogenic factors, i.e. VEGF, PDGF-BB and TGF- $\beta 1$, from macroporous alginate-sulfate/alginate scaffolds (Freeman and Cohen 2009). The scientists took advantage of alginate-sulfate's ability to bind multiple heparin-binding proteins with equilibrium binding constants similar to those observed upon interaction with heparin (Freeman et al. 2008). Macroporous scaffolds prepared by a freeze-drying technique were incubated in single or triple protein solutions (100 ng of total protein loaded). The study revealed that for both alginate-sulfate/alginate and alginate scaffolds, the release patterns from the single and triple protein-loaded systems into DMEM coincided, indicating no mutual effect on the growth factor release rate and sufficient alginate-sulfate ability for multi- protein binding. The incorporation of alginate-sulfate into the alginate matrix significantly prolonged the protein release. The alginate-sulfate/alginate scaffold released VEGF with a small initial burst (20\%), followed by a slower releasing rate. The PDGF-BB and TGF- $\beta 1$ were delivered continuously over an 8-day experiment. The VEGF and PDGF-BB release reached a plateau after 6 days, while TGF- $\beta 1$ continued to be released into the medium. In contrast, pure alginate scaffolds delivered approximately 60 to $80 \%$ of growth factors as an initial burst within the first day. Overall, the results demonstrated sequential delivery of growth factors, i.e. with an initial high level of VEGF followed by PDGF-BB, and a high level of TGF- $\beta 1$ in later days. Moreover, the group showed that subcutaneously implanted triple factor-loaded scaffolds exhibited 3-fold greater blood vessel density and percentage of mature vessels than single growth factor-loaded or untreated scaffolds.

\section{Chemokine delivery}

Chemokines are another group of proteins that play a key role in the wound healing process, particularly within the inflammatory and proliferative phases. They show an ability to induce directed chemotaxis in nearby responsive cells and specifically stimulate the recruitment of leukocytes to inflammatory sites (Rees et al. 2015, Graves et al. 1995).

A detailed study of the adsorption of chemokines stromal cell-derived factor 1 (CXCL12), interferon gamma-induced protein 10 (CXCL10), macrophage inflammatory protein-3 beta (CCL19) and C-C motif chemokine ligand 21 (CCL21) into alginate microspheres and subsequent protein release behavior was published by Wang and colleagues (Wang and Irvine 2011). First, the authors assessed the impact of medium ionic strength on CCL21 release. CCL21 release from the particles increased with an increasing ionic strength of PBS $(30 \mathrm{mM}, \quad 150 \mathrm{mM}$ and $750 \mathrm{mM}$ of $\mathrm{NaCl}$ ). This observation is consistent with electrostatic-mediated binding of CCL21 to the alginate matrix. Furthermore, it was reported that CCL21 loading efficiency increased with decreasing concentration of the protein mixed with microspheres (55\% for $50 \mu \mathrm{g}$ chemokine/mg alginate and up $95 \%$ for concentrations lower than $10 \mu \mathrm{g} / \mathrm{mg}$ ). The chemokine post-loading into alginate microspheres increased in the order $\mathrm{mCXCL} 10<\mathrm{hCCL} 19<\mathrm{hCXCL} 12$ (i.e. $\sim 50 \%, \sim 70 \%$ and $\sim 90 \%$, respectively), inversely to 
the evaluated release rates (ELISA method). CXCL12 loaded at the highest level; however, almost no protein release was detected. The loaded microspheres released chemokines at rates ranging from $7.2 \times 10^{-6}$ to $3.2 \times 10^{-3} \mathrm{ng} / \mathrm{h} /$ particle, covering the physiological range of chemokine release by individual cells. Moreover, in the cases of CCL21, CCL19, and CXCL10, release rates in the physiological range were maintained for at least $24 \mathrm{~h}$. The authors stated that the logarithm of the effective diffusivity of each chemokine in alginate (obtained by fitting the release data to a Fick's law model) correlated well with the net surface charge of the proteins per residue, consistent with charge-mediated interactions between the proteins and the alginate matrix dominating the loading/release behavior. The authors outlined that the investigated systems released a bioactive protein generating functional attractant gradients, both in medium and collagen gels, that were able to attract cells more than hundreds of microns away to make contact with the individual microspheres.

The CXCL12 retention in alginate microcapsules dedicated to encapsulation of $\beta$ TC-tet cells was investigated by Duncanson and Sambanis (2013). The microparticles were prepared directly from the co-solution of alginate and chemokine. The authors reported a large initial CXCL12 loss $(87 \%)$ during the capsule processing. The intracapsular chemokine concentration in the acellular microparticles decreased rapidly during the first 7 days after CXCL12 encapsulation, followed by significantly slower release rate for the next 14 days. When $\beta$ TC-tet cells were encapsulated in the CXCL12/alginate matrix, a rapid decrease in intracapsular CXCL12 concentration was observed. One day after the cell encapsulation, the cellular microparticles contained a two-order lower concentration of CXCL12 (35 ng/ml alginate) than the microparticles without cells $(1,100 \mathrm{ng} / \mathrm{ml}$ alginate $)$. Furthermore, in contrast to acellular microcapsules, the intracapsular CXCL12 concentration significantly declined 2 days after the cell encapsulation, and at day 5 , the chemokine was no longer detectable. The $\beta T C$-tet viability experiment revealed that the presence of CXCL12 in the encapsulation matrix completely abrogated cell apoptosis under hypoxic conditions.

Further work of Duncanson and colleagues presented the sustained release of CXCL12 from alginate microparticles designed for islet transplantation (Chen et al. 2015). The group also observed a significant loss of CXCL12 during the cross-linking process. The release rate of CXCL12 from $1.5 \%$ alginate capsules was $1.75 \mathrm{ng} / \mathrm{ml} / \mathrm{h}$ during the first $24 \mathrm{~h}$ and after 4 days stabilized at $0.18 \mathrm{ng} / \mathrm{ml} / \mathrm{h}$. The release profiles of CXCL12 for alginate concentrations of $1.5 \%$ to $3.3 \%$ showed no differences. Importantly, the encapsulation of pancreatic islets from $\mathrm{C} 57 \mathrm{Bl} / 6$ mice within CXCL12/alginate microbeads resulted in long-term alloand xenoislet survival and function, as well as in a selective increase in intragraft immunocompetent regulatory Tregs cells.

The delivery of ${ }^{125}$ I-labeled CXCL12 from alginate matrices for wound healing applications was investigated by Rabbany et al. (2010). The authors applied surface immobilization of therapeutic agents. First, crosslinked porous alginate discs were covalently coated with spermine chloride thus generating a positive charge on the surface. Then, the discs were incubated overnight in a co-solution of radiolabeled CXCL12 $(1 \mathrm{ng} / \mu \mathrm{l})$ and heparin $(1 \mathrm{U} / \mu \mathrm{l})$ where polyanion heparin formed a polyelectrolyte complex with the coated spermine layer. The scaffolds delivered approximately $60 \%$ of CXCL12 during the first $24 \mathrm{~h}$ in vitro $(0.1 \mathrm{mg} / \mathrm{ml}$ BSA in PBS, $\left.150 \mathrm{~h}, 37^{\circ} \mathrm{C}\right)$. Thereafter, the protein delivery was minimal $(\sim 70 \%$ of total CXCL12 released after $150 \mathrm{~h}$ ). Also in vivo experiments revealed a fast CXCL12 release of $\sim 60 \%$ by 1 day. A beneficial effect of CXCL12 on wound healing in a large animal model was reported. The CXCL12-treated wounds significantly accelerated wound closure compared to nontreated controls. Moreover, $38 \%$ of CXCL12-treated wounds were fully healed by day 9 with very little evidence of scarring as opposed to the controls. This proposed chemokine delivery vehicle was further investigated in vivo in later work (Henderson et al. 2011).

\section{Bone morphogenetic proteins delivery}

Bone morphogenetic proteins (BMP) are a group of cytokines that affect bone as well as cartilage growth and repair, enable skeletal tissue formation during embryogenesis and throughout adulthood. Therefore, they are the most important growth factors in bone formation and healing processes studied in bone tissue engineering. Regarding the use of alginates, several strategies of delivering BPMs within a biomaterial scaffold to the site of injury in order to stimulate the endogenous bone repair process has been proposed (Quinlan et al. 2015, Priddy et al. 2014, Bessa et al. 2008).

Quinlan et al. (2015) focused on the 
development of collagen-hydroxyapatite scaffolds containing alginate microparticles for controlled delivery of rhBMP-2. The rhBMP-2 was encapsulated in spraydried alginate microparticles $(1 \mu \mathrm{g} / \mathrm{mg}$ alginate) with a yield of $45 \%$. The release profile from pure alginate microparticles into PBS revealed an initial burst ( $40 \%)$ during the first 7 days followed by a slower release rate for the next 7 days. At the end of the study (28 days), the microcapsules released $46 \%$ of the initially loaded rhBMP-2. The rhBMP-2/microcapsules were then incorporated into three-dimensional porous collagenhydroxyapatite scaffolds (CHA) with loading of $1.5 \mu \mathrm{g}$ rhBMP-2 per scaffold. The alginate microbeads-CHA constructs exhibited a high initial burst of rhBMP-2, followed by a sustained delivery for the next 7 days. Nevertheless, after 28 days, the alginate microbead-CHA constructs delivered only $15 \%$ of the originally encapsulated rhBMP-2. The authors suggested that a burst release was caused by the aggregation of the encapsulated protein at the surface of the spray-dried alginate microparticles, and thus rhBMP-2 might have diffused more quickly. However, the strong interaction of rhBMP-2 with hydroxyapatite could have hindered the release of a fraction of the protein, resulting in a significantly lower amount of rhBMP-2 released compared to the microparticles alone. An in vitro study of MC3T3-E1 murine pre-osteoblast cells revealed that rhBMP-2 released from alginate-CHA scaffolds maintained its pro-osteogenic effect by enhancing ALP activity of the cells.

Another work investigated the release kinetics of bone forming peptide-1 (BFP-1) labelled with 6-carboxy tetramethyl rhodamine from three-dimensional porous alginate scaffolds (PAS) using fluorescence spectrophotometry (Luo et al. 2016). Scaffolds of two protein concentrations (10 and $100 \mu \mathrm{g}$ of BFP-1 noted as p-PAS-10 and p-PAS-100, respectively) were prepared by a freeze-drying process and protein release from disc specimens into PBS was monitored for 21 days. The results showed that both BFP-1/alginate scaffolds had an excellent sustained-release performance but with a different velocity of peptide release depending on the concentration of the loaded peptide. The p-PAS-100 released $70 \%$ of BFP-1 in the first 9 days, while the p-PAS-10 delivered approximately $30 \%$ of BFP-1 in a relatively sustained rate over 21 days. After 21 days in PBS, the p-PAS-100 scaffold was much larger than the p-PAS-10 one, suggesting faster degradation of p-PAS-100. The accelerated p-PAS-100 degradation might be a reason for quicker protein release from this system. In vitro studies revealed higher cell adhesion, aggregation, proliferation and alkaline phosphatase activity of MG-63 cells for the BFP-1/alginate scaffolds in comparison to the pristine alginate scaffolds, when outstanding bioactivities were observed, especially for the p-PAS-10 scaffold.

Alginate matrices do not sufficiently support the adhesion and ingrowth of bone cells; therefore, they are often enriched by a specific adhesive peptide sequence Arg-Gly-Asp (RGD) that mediates cell attachment (Ruoslahti 1996). The abovementioned strategy was used in the following studies. Priddy et al. (2014) investigated the effect of alginate oxidation on rhBMP-2 release. Irradiated and oxidized-irradiated sodium alginates were first modified with RGD peptide sequences (two sequences/polymer chain). Then, $150 \mu \mathrm{l}$ of the alginate hydrogel containing $500 \mathrm{ng}$ of rhBMP-2 was injected into the PCL nanofiber mesh. Only $20 \%$ of the total loaded protein was released into PBS within 26 days. The oxidation of the irradiated alginates accelerated the BMP-2 release but the difference between the oxidized and non-oxidized samples was noticeable only till day 5 . More than $95 \%$ of the released BMP-2 was eluted by day 3 and day 8 for the oxidized-irradiated and irradiated alginates, respectively. Further, alginate matrices retained $35 \%$ of the loaded rhBMP- 2 after 26 days and the protein was still bioactive as observed by the induction of alkaline phosphatase activity and positive Alizarin Red S staining of MC3T3-E1 cells. Moreover, robust bone regeneration was observed in both groups through 12 weeks in in vivo studies. The histological analyses of bone defects showed enhanced degradation of oxidized-irradiated alginate and suggested the presence of more mature bone after 12 weeks of healing.

The rhBMP-2 was also incorporated into irradiated alginate covalently coupled with $\mathrm{G}_{4}$ RGDASSP peptide sequences (Kolambkar et al. 2011). The RGDalginate solution mixed with rhBMP-2 was gelled with the calcium sulfate slurry and injected into cylindrical molds, giving plugs containing $500 \mathrm{ng}$ of rhBMP-2. The release into PBS containing calcium and magnesium ions was monitored over 21 days. The sample released $71.2 \pm 3.8 \mathrm{ng}$ of rhBMP-2 over 21 days; however, $98.6 \%$ of the total released protein was detected within the first 7 days. The samples at day 0 and 21 were assayed for the amount of entrapped rhBMP-2. The rhBMP-2 amount in the initial alginate matrix (day 0 ) represented only $55.1 \%$ of the total protein added $(275.5 \mathrm{ng} / 500 \mathrm{ng})$, while 
$27.2 \pm 3.3 \mathrm{ng}$ of rhBMP-2 was retained in the hydrogel at the end of the experiment (day 21). Taking into account the abovementioned results, only $25.8 \%$ of the initial amount of rhBMP-2 (71 ng/275.5 ng) was released into the medium during the experiment and $9.9 \%$ of the initial protein concentration $(27.2 \mathrm{ng} / 275.5 \mathrm{ng})$ was still present in the alginate matrix at day 21 , despite the fact that only a minute amount of rhBMP-2 was released. The authors hypothesized that the rhBMP-2 molecules can bind to the alginate matrix, masking the antibody binding site, or degrade over the incubation period. Thus, the actual amount of growth factor present in the hydrogels might have been higher.

On the other hand, the sustained delivery of rhBMP-2 from irradiated RGD-functionalized alginate was reported by McDermott and colleagues (McDermott et al. 2016). In this work, structural porous scaffolds produced from a copolymer of poly(L-lactide) and poly(DL-lactide) (PLDL) as well as electrospun poly( $\varepsilon$-caprolactone) (PCL) nanofiber mesh tubes served as platforms for alginate matrices. The pores and inner core of cylindrical PLDL scaffolds were infused with the alginate hydrogel, while for the PCL tube the alginate hydrogel was injected in situ. The resulting scaffolds, loaded with $500 \mathrm{ng}$ of rhBMP-2, were incubated in PBS for 21 days. The PLDL/ALG such as PCL/ALG constructs delivered rhBMP-2 in a similar manner, i.e. there were no significant differences in release kinetics, total release and protein retention between groups. The scaffolds released approximately $40 \mathrm{ng}$ within 21 days. The amount of rhBMP-2 retained in PCL/ALG scaffolds was $41.4 \pm 21.9 \mathrm{ng}$, while $71.1 \pm 20 \mathrm{ng}$ of rhBMP-2 was detected in PLDL/ALG scaffolds. Considering the above information, the sum of the released and retained protein did not coincide with the initially loaded amount. The authors suggest that it may have been caused by partial protein degradation, losing protein prior to detection or inability of detection by the selected ELISA assay, and thus the release kinetics might have been underestimated.

The natural affinity between heparin and heparinbinding growth factors (e.g. VEGF, FGF-2, BMP) via electrostatic interactions between heparin's negatively charged sulfate groups and the proteins' positively charged amino acid groups can be exploited to control the release of growth factors from alginate matrices. Jeon et al. (2011) proposed an affinity-based growth factor delivery system using photocrosslinked heparin-alginate hydrogels to allow controlled, prolong release of therapeutic proteins. In this study, the BMP-2 release into PBS from four different photocrosslinked alginate systems, i.e. methacrylated alginate hydrogel (ALG), arginylglycylaspartic acid modified methacrylated alginate hydrogel (RGD-ALG), methacrylated heparin-alginate hydrogel (HP-ALG) and arginylglycylaspartic acid modified methacrylated heparinalginate hydrogel (HP-RGD-ALG), was investigated over 3 weeks. It was reported that systems without photocrosslinked heparin released BMP-2 more rapidly than systems containing native heparin. Almost all loaded protein was released from ALG and RGD-ALG hydrogels within the first 7 days. In contrast, the BMP-2 release from the photocrosslinked HP-ALG and HP-RGD-ALG hydrogels was slower and sustained over 3 weeks without an initial burst release $(\sim 60 \%$ released after 1 week, $\sim 70 \%$ after 3 weeks). As there were only minor differences in the release profiles of RGD-containing hydrogels and unmodified ones, alginate hydrogels can be modified with the RDG peptide sequence to allow cell adhesion without influencing the function and benefit of the photocrosslinked heparin. The in vitro studies confirmed that BMP-2 released from photocrosslinked HP-ALG hydrogels retained its biological activity and affected the behavior of the MC3T3-E1 preosteoblasts. Moreover, in vivo experiments showed that BMP-2-loaded HP-ALG hydrogels induced significantly more osteogenesis than BMP-2-loaded unmodified ALG hydrogels, with 1.9-fold greater peripheral bone formation and 1.3-fold greater calcium content 8 weeks after implantation. The photocrosslinked heparin-alginate hydrogels have been reported to exhibit sustained and controllable release of other growth factors, e.g. VEGF, TGF- $\beta 1$, and FGF-2.

\section{Conclusions}

During the last 25 years, alginate properties, characterization and preparation have been extensively studied demonstrating their applicability as biomaterials. Due to outstanding physicochemical properties and especially mild crosslinking conditions, alginates are a valuable platform for protein encapsulation. Protein loading and release are strongly affected by the type and characteristics of the alginate matrix, by protein characteristics, by the mutual interactions between proteins and alginate matrix as well as by the processing method. Crosslinking type and crosslinking density significantly affect release through hindering the protein in a more or less crosslinked gel. Alginates with high G-blocks content yield stiffer, brittle and mechanically more stable hydrogels, while high M-blocks content leads to soft and 
more elastic gels with higher water adsorption and easier ion exchange. Neutral biomolecules and proteins with a low pI diffuse through the alginate hydrogel network with diffusion coefficients depending on the ratio of their molecular weight to the network mesh size; they are released quickly, usually with a burst release effect. On the contrary, proteins with a high $\mathrm{pI}$ can interact ionically with a negatively charged alginate matrix what can strongly slow down if not block protein release. Several modifications have been proposed to tune alginate binding and release of proteins, adjusting at the same time alginate degradability, mechanical stiffness, swelling, gelation properties, protein-matrix interaction and/or cell affinity. However, the often observed high burst effect and short release times will still represent challenges for researchers. To this end, it will be necessary to put scientific effort on comprehensive understanding of interactions between particular proteins and a negatively charged alginate matrix. Such information could serve as engineering design criteria to develop new modifications of the alginate matrix to achieve well control over the protein release kinetics as well as preserving protein activity for prolonged release times. Additionally, further research activities should also reflect current deep knowledge about regeneration processes on cellular levels (e.g. during wound healing or vascularization) leading to requirements for multiply growth factor delivery. Following that, further important issue to be solved is estimation of optimal delivered GFs doses based on demands for regeneration of particular tissues; this could be achieved when combining proposed in vitro evaluation experiments with appropriate in vivo studies. Finally, alginate-based systems for delivery of proteins and especially of growth factors are of great interests in constructing of bioactive biomaterials. The proper selection of the alginate type, crosslinking method as well as processing method with respect to characteristics of delivered proteins could provide delivery systems with tailor-made characteristics for particular tissue engineering applications.

\section{Conflict of Interest}

There is no conflict of interest.

\section{Acknowledgements}

This work was supported by the Ministry of Education, Youth and Sports of the CR within the National Sustainability Program II [Project BIOCEV-FAR LQ1604].

\section{References}

AHMED EM: Hydrogel: Preparation, characterization, and applications: A review. J Adv Res 6: 105-121, 2015.

AUGUST AD, KONG HJ, MOONEY DJ: Alginate hydrogels as biomaterials. Macromol Biosci 6: 623-633, 2006.

BAJPAI M, SHUKLA P, BAJPAI SK: Ca(II)+Ba(II) ions crosslinked alginate gels prepared by a novel diffusion through dialysis tube (DTDT) approach and preliminary BSA release study. Polym Degrad Stab 134: 22-29, 2016.

BESSA PC, CASAL M, REIS RL: Bone morphogenetic proteins in tissue engineering: the road from laboratory to clinic, part II (BMP delivery). J Tissue Eng Regen Med 2: 81-96, 2008.

BOUIS D, KUSUMANTO Y, MEIJER C, MULDER NH, HOSPERS GAP: A review on pro- and anti-angiogenic factors as targets of clinical intervention. Pharmacol Res 53: 89-103, 2006.

CASTRO GR, KAMDAR RR, PANILAITIS B, KAPLAN DL: Triggered release of proteins from emulsan-alginate beads. J Control Release 109: 149-157, 2005.

CHEN T, YUAN J, DUNCANSON S, HIBERT ML, KODISH BC, MYLAVAGANAM G, MAKER M, LI H, SREMAC M, SANTOSUOSSO M, FORBES B, KASHIWAGI S, CAO J, LEI J, THOMAS M, HARTONO C, SACHS D, MARKMANN J, SAMBANIS A, POZNANSKY MC: Alginate encapsulant incorporating CXCL12 supports long-term allo- and xenoislets transplantation without systemic immune suppression. Am J Transplant 15 : 618-627, 2015.

DAI C, WANG B, ZHAO H, LI B, WANG J: Factors affecting protein release from microcapsule prepared by liposome in alginate. Colloids Surf B Biointerfaces 42: 253-258, 2005.

DAI C, WANG B, ZHAO H, LI B, WANG J: Preparation and characterization of liposomes-in-alginate (LIA) for protein delivery system. Colloids Surf B Biointerfaces 47: 205-210, 2006.

DUNCANSON S, SAMBANIS A: Dual factor delivery of CXCL12 and Exendin-4 for improved survival and function of encapsulated beta cells under hypoxic conditions. Biotechnol Bioeng 110: 2292-2300, 2013. 
EDELMAN ER, NUGENT MA, SMITH LT, KARNOVSKY MJ: Basic fibroblast growth factor enhances the coupling of intimal hyperplasia and proliferation of vasa vasorum in injured rat arteries. J Clin Invest 89: 465-473, 1992.

ELDIN MSM, KAMOUN EA, SOFAN MA, ELBAYOMI SM: L-Arginine grafted alginate hydrogel beads: A novel pH-sensitive system for specific protein delivery. Arab J Chem 8: 355-365, 2015.

FREEMAN I, COHEN S: The influence of the sequential delivery of angiogenic factors from affinity binding alginate scaffolds on vascularization. Biomaterials 30: 2122-2131, 2009.

FREEMAN I, KEDEM A, COHEN S: The effect of sulfation of alginate hydrogels on the specific binding and controlled release of heparin-binding proteins. Biomaterials 29: 3260-3268, 2008.

GRAVES DT, JIANG Y: Chemokines, a family of chemotactic cytokines. Crit Rev Oral Biol Med 6: 109-118, 1995.

GOMBOTZ WR, WEE SF: Protein release from alginate matrices. Adv Drug Deliv Rev 31: 267-285, 1998.

GU F, AMSDEN B, NEUFELD R: Sustained delivery of vascular endothelial growth factor with alginate beads. J Control Release 96: 463-472, 2004.

HARIYADI DM, MA Y, WANG Y, BOSTROM T, MALOUF J, TURNER MS, BHANDARI B, COOMBES AGA: The potential for production of freeze-dried oral vaccines using alginate hydrogel microspheres as protein carriers. J Drug Del Sci Tech 24: 178-184, 2014.

HENDERSON PW, SINGH SP, KRIJGH DD, YAMAMOTO M, RAFII DC, SUNG JJ, RAFII S, RABBANY SY: Stromal-derived factor-1 delivered via hydrogel drug-delivery vehicle accelerates wound healing in vivo. Wound Rep Reg 19: 420-425, 2011.

HONNEGOWDA TM, KUMAR P, UDUPA EG, KUMAR S, KUMAR U, RAO P: Role of angiogenesis and angiogenic factors in acute and chronic wound healing. Plast Aesthet Res 2: 243-249, 2015.

JAY SM, SALTZMAN WM: Controlled delivery of VEGF via modulation of alginate microparticle ionic crosslinking. J Control Release 134: 26-34, 2009.

JEON O, POWELL C, SOLARIO LD, KREBS MD, ALSBERG E: Affinity-based growth factor delivery using biodegradable, photocrosslinked heparin-alginate hydrogels. J Control Release 154: 258-266, 2011.

JEROME P, PAGUES JP, LINDEN E, RIJNA CJM, SAGIS LMC: Preparation methods of alginate nanoparticles. Adv Colloid Interface Sci 209: 163-171, 2016.

KAYGUSUZ H, ERIM FB: Alginate/BSA/montmorillonite composites with enhanced protein entrapment and controlled release efficiency. React Funct Polym 73: 1420-1425, 2013.

KHANNA O, MOYA ML, GREISLER HP, OPARA EC, BREY EM: Multilayered microcapsules for the sustainedrelease of angiogenic proteins from encapsulated cells. Am J Surg 200: 655-658, 2010.

KOEHLER J, BRANDL FP, GOEPFERICH AM: Hydrogel wound dressings for bioactive treatment of acute and chronic wounds. Eur Polym J 100: 1-11, 2018.

KOLAMBKAR YM, DUPONT KM, BOERCKEL JD, HUEBSCH N, MOONEY DJ, HUTMACHER DW, GULDBERG RE: An alginate-based hybrid system for growth factor delivery in the functional repair of large bone defects. Biomaterials 32: 65-74, 2011.

KUO CK, MA PX: Ionically crosslinked alginate hydrogels as scaffolds for tissue engineering: Part 1. Structure, gelation rate and mechanical properties. Biomaterials 22: 511-521, 2001.

LEE KY, PETERS MC, MOONEY DJ: Comparison of vascular endothelial growth factor and basic fibroblast growth factor on angiogenesis in SCID mice. $J$ Control Release 87: 49-56, 2003.

LEE KY, MOONEY DJ: Alginate: Properties and biomedical applications. Prog Polym Sci 37: 106-126, 2012.

LEE K, SILVA EA, MOONEY DJ: Growth factor delivery-based tissue engineering: general approaches and a review of recent developments. $J$ R Soc Interface 8: 153-170, 2011.

LEONARD M, RASTELLO DE BOISSESON M, HUBERT P, DALENCON F, DELLACHERIE E: Hydrophobically modified alginate hydrogels as protein carriers with specific controlled release properties. $J$ Control Release $\mathbf{9 8}$ : 395-405, 2004.

LIU L, WU F, JU XJ, XE R, WANG W, NIU CH, CHU LY: Preparation of monodisperse calcium alginate microcapsules via internal gelation in microfluidic-generated double emulsions. J Colloid Interface Sci 404: 85-90, 2013.

LODISH H, BERK A, ZIPURSKY S, MATSUDAIRA P, BALTIMORE D, DARNELL J: Molecular Cell Biology, 4th Edition. W. H. Freeman, New York, 2000, 1184 p. 
LUO Z, YANG Y, DENG Y, SUN Y, YANG H, WEI S: Peptide-incorporated 3D porous alginate scaffolds with enhanced osteogenesis for bone tissue engineering. Colloids Surf B Biointerfaces 143: 243-251, 2016.

MCDERMOTT AM, MASON DE, LIN ASP, GULDBERG RE, BOERCKEL JD: Influence of structural load-bearing scaffolds on mechanical load- and BMP-2-mediated bone regeneration. J Mech Behav Biomed Mater 62: 169-181, 2016.

MOYA ML, LUCAS S, FRANCIS-SEDLAK M, LIU X, GARFINKEL MR, HUANG JJ, CHENG MH, OPARA EC, BREY EM: Sustained delivery of FGF-1 increases vascular density in comparison to bolus administration. Microvasc Res 78: 142-147, 2009.

MOBUS K, SIEPMANN J, BODMEIER R: Zinc-alginate microparticles for controlled pulmonary delivery of proteins prepared by spray-drying. Eur J Pharm Biopharm 81: 121-130, 2012.

MOMOH FU, BOATENG JS, RICHARDSON SCW, CHOWDHRY BZ, MITCHELL JC: Development and functional characterization of alginate dressing as potential protein delivery system for wound healing. Int J Biol Macromol 81: 137-150, 2015.

MUMPER RJ, HOFFMAN AS, PUOLAKKAINEN PA, BOUCHARD LA, GOMBOTZ WR: Calcium-alginate beads for the oral delivery of transforming growth factor- $\beta 1$ (TGF- $\beta 1$ ): stabilization of TGF- $\beta 1$ by the addition of polyacrylic acid within acid-treated beads. $J$ Control Release 30: 241-251, 1994.

PAWAR SN, EDGAR KJ: Alginate derivatization: A review of chemistry, properties and applications, Biomaterials 33 : 3279-3305, 2012.

PRIDDY LB, CHAUDHURI O, STEVENS HY, KRISHNAN L, UHRIG BA, Willett NJ, GULDBERG RE: Oxidized alginate hydrogels for bone morphogenetic protein-2 delivery in long bone defects. Acta Biomater 10: 4390-4399, 2014.

QUINLAN E, LOPEZ-NORIEGA A, THOMPSON E, KELLY HM, CRYAN SA, O'BRIEN FJ: Development of collagen-hydroxyapatite scaffolds incorporating PLGA and alginate microparticles for the controlled delivery of rhBMP-2 for bone tissue engineering. J Control Release 198: 71-79, 2015.

RABBANY SY, PASTORE J, YAMAMOTO M, MILLER T, RAFII S, ARAS R, PENN M: Continuous delivery of stromal cell-derived factor-1 from alginate scaffolds accelerates wound healing. Cell Transplant 19: 399-408, 2010.

RAHMANI V, SHEARDOWN H: Protein-alginate complexes as pH-/ion-sensitive carriers of proteins. Int J Pharm 535: 452-461, 2018.

REES PA, GREAVES NS, BAGUNEID M, BAYAT A: Chemokines in wound healing and as potential therapeutic targets for reducing cutaneous scarring. Adv Wound Care 4: 687-703, 2015.

ROUWKEMA J, KHADEMHOSSEINI A: Vascularization and angiogenesis in tissue engineering: beyond creating static networks. Trends Biotechnol 34: 733-745, 2016.

RUOSLAHTI E: RGD and other recognition sequences for integrins. Annu Rev Cell Dev Biol 12: 697-715, 1996.

RUVINOV E, LEOR J, COHEN S: The effects of controlled HGF delivery from an affinity-binding alginate biomaterial on angiogenesis and blood perfusion in a hindlimb ischemia model. Biomaterials 31: 4573-4582, 2010.

SILVA EA, MOONEY DJ: Spatiotemporal control of vascular endothelial growth factor delivery from injectable hydrogels enhances angiogenesis. J Thromb Haemost 5: 590-598, 2007.

SILVA EA, MOONEY DJ: Effects of VEGF temporal and spatial presentation on angiogenesis. Biomaterials 31: 1235-1241, 2010.

SIVADAS N, O'ROURKE D, TOBIN A, BUCKLEY V, RAMTOOLA Z, KELLY JG, HICKEY AJ, CRYAN SA: A comparative study of a range of polymeric microspheres as potential carriers for the inhalation of proteins. Int J Pharm 358: 159-167, 2008.

STROPPEL WL, WHITE JC, HORAVA SD, BHATIA SR, ROBERTS SC: Transport of biological molecules in surfactant-alginate composite hydrogels. Acta Biomater 7: 3988-3998, 2011.

SUN J, TAN H: Alginate-based biomaterials for regenerative medicine applications. Materials 6: 1285-1309, 2013.

SZEKALSKA M, PUCIBOWSKA A, SZYMANSKA E, CIOSEK P, WINNICKA K: Alginate: Current use and future perspectives in pharmaceutical and biomedical applications. Int J Polym Sci 2016: 7697031, 2016. 
TILAKARATNE HK, HUNTER SK, ANDRACKI ME, BENDA JA, RODGERS VGJ: Characterizing short-term release and neovascularization potential of multi-protein growth supplement delivered via alginate hollow fiber devices. Biomaterials 28: 89-98, 2007.

VENKATESAN J, BHATNAGAR I, MANIVASAGAN P, KANG KH, KIM SK: Alginate composites for bone tissue engineering: a review. Int J Biol Macromol 72: 269-281, 2015.

WANG Y, IRVINE DJ: Engineering chemoattractant gradients using chemokine-releasing polysaccharide microspheres. Biomaterials 32: 4903-4913, 2011.

WANG Z, WANG ZH, LU WW, ZHEN W, YANG D, PENG S: Novel biomaterial strategies for controlled growth factor delivery for biomedical applications. NPG Asia Mat 9: e435, 2017.

WELLS LA, SHEARDOWN H: Extended release of high $\mathrm{p} I$ proteins from alginate microspheres via a novel encapsulation technique. Eur J Pharm Biopharm 64: 329-335, 2007. 